\title{
Queer Memoir: Public Confession and/ as Sexual Practice in Eve Kosofsky Sedgwick's A Dialogue on Love
}

\author{
ELIZABETH STEPHENS
}

In a revealing exchange during the documentary Derrida, the filmmakers ask Derrida what he himself would be most curious to know about the lives of the philosophers whose work had influenced his own. 'Their sex lives', Derrida replies, without hesitation. 'So, can we ask you about your sex life?' the interviewers ask. Derrida looks unimpressed. 'No', he says.

This staged, even solicited, refusal to provide any information about a subject he himself has raised as one of both personal interest and intellectual significance represents an exemplary moment in this film, which grapples with what it means to document a life - especially the life of a philosopher whose own work has so relentlessly problematised widely-held assumptions about the relationship between subjective experience and representational economies. From Derrida's earliest theorisations of the writing process - in which, through an analysis of the autobiography of Jean-Jacques Rousseau, he drew a parallel between the way writing was culturally positioned as the 'dangerous supplement' of speech and the way Rousseau understood masturbation as the dangerous supplement of heterosexual coitus ${ }^{1}$ - Derrida has argued that all writing is inevitably inflected by the affective investments and the specificity of a subject whose textual presence is, in turn, simultaneously mediated by wider systems of language and representation which pre-scribe the terms in which (auto)biographies can be written.

The implications of this for contemporary understandings of first-person writing - and particularly of the possibility of self-representation for marginalised subjects examined within the context of queer studies - are most succinctly articulated in Derrida's theorisation of the signature, in which the concept of the signature provides a way to rethink the relationship between author and text by reconceptualising the autobiographical subject as a form of textual inscription. That is, the idea of the signature provides a conceptual

\footnotetext{
1 The 'dangerous supplement' is the term Derrida uses to describe the paradoxical relationship between the dominant and marginalised terms of a binary opposition, in which the terms are seen both as opposites, hence exterior to each other, but also as structurally and semantically dependent on each other, and hence inextricably interwoven: while the supplement 'is exterior to ... [and] supervenes upon' the dominant term, it does so 'always by way of compensation for [sous l'espèce de la suppléance] what ought to lack nothing at all in itself' (Of Grammatology 145).
} 
framework in which authorial presence is neither identified as the source of textual truth nor entirely simply erased from the text the author produces, but is instead rethought as a dynamic that is mobilised in and through the practice of writing. ${ }^{2}$ In Glas, Derrida theorises the signature through a comparative analysis of Hegel's apparently objective philosophical style and the highly idiosyncratic autobiographical fiction of Jean Genet, problematising the assumed 'contradiction between a discourse of philosophical teaching that represses, effaces and excludes the signature, and Genet's poetic text that carries his own signature, is or becomes or incorporates his signature' (30). ${ }^{3}$ This is the double impossibility of autobiography, of all writing, with which Derrida confronts his own would-be biographers: all writing is inscribed by the authorial subject whose specificity both shapes and eludes the text he/she produces.

While it may seem unusual to begin a study of Eve Kosofsky Sedgwick's $A$ Dialogue on Love with this overview of the conceptualisation of autobiography in the work of another theorist, such problematisations of the status and singularity of the autobiographical subject lay at the heart of Sedgwick's own text and, more broadly, of those areas of queer studies principally concerned with issues of self-representation. The entire text of $A$ Dialogue on Love reads like the result of having said 'yes' to the question about the sex life of the philosopher Derrida both posed and refused to answer. Like Derrida, Sedgwick recognises the sexual and affective attachments of the writing subject as integral to the text s/he produces; like Derrida, she also recognises the extent to which this sexual dimension - and, indeed, the importance attributed to sexuality

2 In Signéponge/Signsponge, Derrida identifies three 'modalities' of the signature. The first is 'the signature in the proper sense ... the act of someone not content to write his proper name (as if he were filling out an identity card), but engaged in authenticating (if possible) the fact that it is indeed he who writes' (52-54). That is to say, it is the autograph, the 'repeatable, iterable, imitable form' of the name ('Signature Event Context' 328). The second modality is 'the set of idiomatic marks that a signer might leave by accident or intention in his product. ... We sometimes call this the style, the inimitable idiom of a writer, sculptor, painter, or orator' (Signéponge/Signsponge 54). Just as the signature bears the recognisable mark of its author's (hand)writing style, so does the author's recognisable literary style allow us to identify his/her text as, for instance, Derridean. Thirdly, there is the 'general signature, or signature of the signature, the fold of the placement in the abyss where ... the work of writing designates, describes and inscribes itself as act. ... I refer to myself, this is writing, I am a writing' (ibid. 54).

3 Derrida takes Hegel and Genet as the two case studies through which to examine this issue precisely because their own respective approaches appear so fundamentally opposed. In contrast to Genet's insistently self-referential prose, Hegel's writing represents itself as objective and impartial, uninflected by autobiographical concerns: 'The first column devoted to Hegel emphasizes the fact that he doesn't sign, that a philosopher doesn't sign, that the name of a philosopher isn't essential to his discourse,' Derrida explains in 'Countersignature' (31). Derrida's argument in Glas, however, is that Genet's writing makes visible dynamics that exist within all writing, including the depersonalised language of philosophers: all writing reveals traces of its author's style or 'signature.' Arguing against the assumption, which he argues is evident in many philosophical texts, that the specificity of the writing subject can be erased in the articulation of some abstract philosophical Truth, Derrida contends that philosophy itself must be understood as written: the metaphors and allusions in which it couches itself are not ornamental or extraneous to it, but an essential and internal part of its meaning in a way it often tries to obscure. Truth is never 'present' in a purely objective, transparent articulation of Reason and Logic, but is always mediated both through the rhetoric, metaphors and figures of speech it deploys, as well as inflected by the specificity of the subject who uses it. 
itself in the construction of subjectivity and textuality - is a product of a particular cultural and historical context. A Dialogue on Love is, it should be noted, written immediately after the publication of Epistemology of the Closet, whose Foucauldian central argument is that the contemporary understanding of sexuality as a private or secret or essential part of oneself is the product of new public spaces and institutions emergent during the nineteenth century. In her theorisation of the 'glass closet', for instance, Sedgwick contends that the trope of the closet is often invoked in nineteenth-century fiction as a means by which to represent sexualities that are publicly constructed as something hidden and private.

The text of $A$ Dialogue on Love both continues and extends the argument about the importance attributed to sexuality to the construction and experience of subjectivity found in Epistemology of the Closet. A first-person narrative that traces the course of therapy Sedgwick undertook subsequent to her treatment for breast cancer, which included a mastectomy and the depression that followed, ADialogue on Love provides a detailed account of Sedgwick's relationship to and understanding of her body and sexuality. That someone who has just published a major reconceptualisation of the binarised relationship between public and private should produce, immediately afterwards, a public account of her own intensely personal experiences might strike the reader as a rather perverse act and this perversity is, explicitly, a large part of the appeal such an act holds for Sedgwick, a means by which to inscribe the specificity of her own sexual subjectivity within the representational and epistemological contexts by which it is produced.

In this way, Sedgwick, like Derrida, draws her readers' attention to the impossibility of the fascination at the centre of her own writing, and of the (auto)biographical act in which it is grounded: autobiography is a public account that produces particular aspects of a life as personal and private in order to 'reveal' them to the reader. In the stance taken by both of these theorists - manifested, on the one hand, by the awkwardness and dead silence that follows Derrida's refusal to respond to his interviewers' prompted question, and, on the other, by what Sedgwick herself refers to as the 'teeth-grinding embarrassment' (171) of her own voluble response - the double impossibility of sexual self-representation is made strikingly clear: the topic of sex(uality) is that which repeatedly imposes itself as a question without a (fixed) answer, but which one is nonetheless impelled repeatedly to pose. In Epistemology of the Closet, Sedgwick famously asserted that sexuality was so culturally central and significant that 'virtually any aspect of modern Western culture must be, not merely incomplete, but damaged in its central substance to the degree that it 
does not incorporate [its] critical analysis' (1). ${ }^{4}$ The start of A Dialogue on Love, however, problematises her own attempt to discuss her sexuality before the text has even begun. Sedgwick reflects at the start of her sessions with her therapist, Shannon: 'I know I want to talk about sex, it's what I do for a living and I'm good at that. But my own sexuality - do I even have one?' (42). Thus while Sedgwick recognises, like Derrida, the role of one's own sexuality and affective investments in the production of knowledge and texts, she also recognises the simultaneous impossibility of talking about one's 'own' sexuality - either as something one owns or as a singular thing.

Like Irigaray, then, Sedgwick understands her sexuality as 'not one' - that is, as unrecognisable through the conceptual categories by which sexuality is conventionally understood, largely because it is neither singular nor unified. ${ }^{5}$ In Sedgwick's account, her sexuality operates across three different, often disconnected, fields. Firstly, there is the sex she has with her partner, a 'hygienic and routinised' practice of 'vanilla sex', undertaken 'on a weekly basis, in the missionary position, in daylight, immediately after a shower, with one person of the so-called opposite sex, to whom I've been legally married for almost a quarter of a century' (44). Secondly, there is the sex she has or thinks about alone, in masturbation and fantasy, which is focused primarily on an S/M eroticism and which she understands as most expressive of what she would identify as her 'sexuality'. Finally, there is her professional and social inclination to '(homo)sexualise' her texts and contexts, her role as someone 'whose work and politics and friendship, whose interpretive and teaching and lecturing life, talking and joking, reading, thinking, whatever, are probably as infused with sexual meanings and motives and connections - gay ones - as anybody's you're ever likely to meet' (44; original emphasis). This multiple and dispersed range of sexual experiences and expressions is not something Sedgwick is interested to - or knows how to - unify into one sexuality, or one subject position, or one kind of narrative. It is precisely this, as the rest of this paper will explore, that makes sex so central to and exemplary of the fraught practice of autobiography for Sedgwick, and which transforms A Dialogue on Love from a 'straight' autobiography into a queer memoir - it is a text that inscribes a 'self' which is not one.'

This is the issue at the heart of Sedgwick's text: A Dialogue on Love is not an attempt to provide a direct or unmediated account of her experience in therapy;

\footnotetext{
4 Sedgwick is speaking here more particularly of the binarisation of the categories of hetero- and homosexuality, emergent during the nineteenth century.

5 Irigaray argues that the 'at least two (lips)' of the female sex both materialise and metaphorise women's absence from the phallogocenric systems within which conventional notions of sexuality are conceptualised: 'Whence the mystery that woman represents in a culture claiming to count everything, to number everything by units, to inventory everything as individualities. She is neither one nor two. Rigorously speaking, she cannot be identified either as one person, or as two. She resists all adequate definition' (26; original emphasis).
} 
rather, it is a queer investigation of the terms in which such experiences can be inscribed, posing the question of how one might write about both sexuality and affective relationships — which, as she acknowledges, occupy such a prominent position in her own professional and personal life - when the conceptual terms and narrative trajectories available in which to articulate these circumscribe so much of what can be said and thought about them. In particular, Sedgwick wonders how she might enter the discursive space of therapy, find a way to articulate herself within a therapeutic narrative, while avoiding recuperation into its normalising narratives. As Foucault has so influentially argued, the nineteenth-century emergence of psychiatry was a crucial part of the disciplinary society developing during the same period, and came to constitute one of its key technologies of normalisation. As Sedgwick recognises, much of what she says about her own sexuality in A Dialogue on Love is easily, almost too easily, recuperable into pathologising narratives, psychiatric discourses. She notes: 'the snowballing of gay-lesbian studies has given me a big, additional reason for being shy about my actual sexuality (if this even is one). Since it makes such a bad fit - and it's been so much easier just to put other people's queer sexuality in the place of my own, the place where, anyway, so much of my identification, passion, and thinking have always lived' (171). Within standard therapeutic narratives, as Shannon notes in the extracts from his case files that Sedgwick includes throughout her text, the non-unified multiplicity of Sedgwick's sexualities would be identified as a failure of subjective integration:

We return to sex and talk about how hard it is to focus on this topic. Part of it is the fact that, while sex is a presence in E's life in myriad ways, these ways are so discontinuous. This makes it hard for her or us to form a coherent narrative understanding of it. E notes that all the elements of it were there in her early years but have become more fragmentedinstead of more integrated - in the ensuing years. (158)

As a result, he continues a little later, Sedgwick has 'no sexual subject position to organise her sensations' (186).

And yet, despite the context in which her discussion of sexuality tales place, $A$ Dialogue on Love is not the account of Sedgwick's normalisation in and through the therapeutic process, the Foucauldian confession of her sexuality. Neither Sedgwick nor Shannon suggests that her dispersed sexualities constitute a problem or pathology: she seems content to enjoy each on their different levels and to be uninterested in unifying these into a coherent sexual identity. This is, of course, exactly the position one would expect from one of the founding figures of queer theory, who defined queer as the open mesh of possibilities, gaps, overlaps, dissonances and resonances, lapses and excesses of meaning when constituent elements of anyone's gender, of anyone's sexuality aren't made (or can't be made) to signify monolithically' (Tendencies 8). Sedgwick is not 
interested, to paraphrase Foucault, in 'making the difficult confession of who she is', in subjugating herself before the master narrative of her therapist. The way she develops as the best means by which to avoid this, as the title of her book indicates, is to ensure the therapeutic process does not function as a clash of monologues, in which the therapeutic narrative comes to correct and replace that of the patient, but rather to transform it into a genuine dialogue, one in whose affective dimension she can trust. It is in this respect that Sedgwick's project differs markedly from Derrida's, and it is precisely this difference that propels her exhaustive response to the question of the sex life of the philosopher, and her examination of its role in shaping the theoretical work she produces. Whereas Derrida's work focuses primarily on the possibilities and difficulties of autobiographical writing as philosophical problems - albeit problems in which he has a deep, and culturally-encouraged, personal interest-Sedgwick is motivated by her stated aim to change herself, to relieve the debilitating effects of depression: 'I need you to change me', she says to Shannon (51; original emphasis). To herself, she resolves: 'If I can fit the pieces of this self back together at all, I don't want them to be the way they were' (7).

A Dialogue on Love is the account of Sedgwick's attempt to establish a productive space in which such change can occur, as well as a record of her reservations about the possibilities of achieving this. She makes very clear to Shannon from the outset that she wants to avoid turning her therapy into a 'disciplinary machine', and that she sees placing positive affective relationships at the heart of the process as the best way to counteract this possibility. She says:

There's something about pleasure that might be important. I don't know how to say it properly; I've gotten hold of an intuition that if things can change for me, it won't be through a very grim process. ... I used to take one deep masochistic breath, and determine I was ready to surrender to the disciplinary machine - in enough pain to have to do it - but then of course I didn't know how to, and couldn't sustain my resolve anyway; and nothing about the therapy would work. Now it seems that if anything can bring me through to real change, it may only be some kind of pleasure. (45)

There are no doubt compelling reasons why someone recovering from chemotherapy and a mastectomy, now suffering depression, would want to minimise grim experiences and prioritise pleasure; Sedgwick needs to be able to trust that Shannon has something else to offer than a reinscription of her identity and experience by the 'disciplinary machinery' of therapy. But the kind of reciprocity and mutuality she is looking for is also a necessary prerequisite for the queer ethics and politics to which she is committed; they are the very condition of possibility in which different kinds of knowledge, social structures, relationships and forms of (self-)representation might emerge. 
Sedgwick is, initially, unconvinced by Shannon's ability to enter into such a mutual process. She worries that he is too conservative to help her, not smart enough; that he will be '[t]oo dumb or too nice' (51). Most importantly, she fears he will lack empathy and understanding as a result of his own socialised position as a heterosexual male: 'He looks like a guy. Someone who's never viewed his body, or had or wanted it viewed, much as an object of desire. Someone also for whom, maybe - unlike me or most anyone I love - his entitlement to exist, the OK-ness of being who and as he is, has never seemed very seriously questionable. It worries me: how could someone like that have learned to think or feel?' (910). Yet Sedgwick and Shannon do establish a dialogue, across the space of these differences, as reflected, most obviously, by Sedgwick's increasing inclusion of Shannon's case notes within the space of her own text, so that Sedgwick is less the sole author of an autobiographical narrative than a participant in a dialogue about affective relationships and experiences. This is, indeed, what $A$ Dialogue on Love is about: not an autobiographical account of Sedgwick's own experience in therapy - does she even have one? - but of the affective bonds, the love, she shares with her therapist. It is important to her, Sedgwick notes, that Shannon's love is somehow impersonal (that he loves her, but not only her, as she puts it), while her own love refrains from imposing itself, from seeing itself as a demand that must be acknowledged. Early on in the text, she writes:

I've already developed a strategy for 'We have to stop now' [the phrase that signals the end of each session]. In fact, most hours - not this one-I expect the sentence before it comes.

When it does come, I'll hop from the couch with an almost eager promptness. It's the same way, when I used to be in love with someone who wasn't in love with me, I would pantomime, 'But I'll never be a burden to you'. It signifies the supposed lightness of my demand and presence. (50)

The word 'supposed' is doing a lot of work here (not least because Sedgwick also confides that she sometimes drives past Shannon's office on non-consultation days, taking comfort in seeing the light in his window). For Sedgwick, however, a certain detachment within the space of the intimate relationship is a necessary prerequisite to a positive therapeutic experience, producing the space of openness in which she is able to establish dialogue and effect a personal change.

The extent to which Sedgwick is ultimately reassured about the reciprocity of the dialogue she establishes with Shannon is reflected in the increasing space she makes available for the inclusion of his case notes as the text continues, even granting him the concluding lines to a narrative that has become progressively more co-written. Noting (in contrast to her own comment above) that Sedgwick has a tendency towards 'not being able to stop', he remarks: 'She remembers 
telling me how she waits for someone to tell her she can "stop now" — eg, die. She imagines me doing this some time in the future. She also talks about having come to be able to hear a voice like my voice inside herself when it is quiet that she can trust and have confidence in. I can imagine the voice telling her she can stop' (220). This internalisation of Shannon's voice reflects the level of trust that Sedgwick has developed in her therapist, but it is not, of course, an unreciprocated influence: rather, and as the comments from Shannon's case notes come to occupy more and more of the text, it is evident how much Shannon himself had internalised Sedgwick's voice, sometimes writing in the first-person from her point of view, or reflecting explicitly on his own sexuality or subject position in ways Sedgwick has clearly prompted him to think about.

And it is precisely in this respect that A Dialogue on Love reads more like a queer memoir than 'straight autobiography', whose conventions it largely resists. For a start, the narrative avoids a traditional linear trajectory and teleological function, not least because the main character declares that she has lost interest in the story and wanders off before the end of the text, leaving Shannon to finish the account. She realises that she finds the discussions of her sexual fantasies 'boring, banal, stereotypic' (174), rather than revelatory, and loses interest in further recounting them. Rather more pressingly, however, Sedgwick discovers during the writing of this text that her cancer has returned, and this news propels her into what she characterises as an 'arts and crafts mania': 'I've started to elope from my school and writing, flying towards this stuff with the stealth, joy, almost the guilt of adultery' (199). Despite the fact Sedgwick remains the central character in a text written in the first person, A Dialogue on Love is nonetheless not, as I have indicated above, an autobiographical account of one subject's life or experiences; rather, it is the record of the intimate relationship that develops between two people (at least one of whom already identifies as multiple).

In Glas, Derrida claims that his theorisation about the relationship between subjectivity and writing occurs in the spaces between his two separate columns on Hegel and Genet. The dialogue, and the love, between Sedgwick and Shannon similarly take place in the space(s) between them, where their voices are able to speak to and be heard by one another. The first-person status of the narrator, so central to traditional autobiography, is here textually dispersed, with Sedgwick's account augmented both by Shannon's notes and the haibun (short Japanese poems classically used to describe travel) that break up the text. In this way, A Dialogue on Love is not the record of Sedgwick's therapy sessions so much as 'the writing of Shannon and me' (203); it is about intimacy, not identity, affective dynamics rather than the therapeutic narrative. And yet, despite its focus on the unstable dynamic of love, rather than the life-story of a unified self, the queer narrator of this generically anomalous text nonetheless 
remains an insistent, and dominant, presence within it. Despite her professed embarrassment in talking about her 'own' sexuality and her willingness 'to put other people's queer sexuality in the place of my own', it is still Sedgwick's own, often perverse, sexualised investment that propels the narrative forward: 'sexiness and embarrassment are two things that won't ever stay separate for me', she tells Shannon, noting to the reader: 'it's exciting for me to talk about this with him' (171; original emphasis). And, presumably, to talk about it to usthe public readers of this private record. A Dialogue on Love is, amongst other things, the inscription of this excitement, of the compulsively 'masturbating girl' Sedgwick identifies as, here and elsewhere, who fantasises at great and tireless length (as she tells Shannon) about the public exposure of her private desires. In this way, Sedgwick's queer specificity finds its way into her text, into her therapy, not through an autobiographical account of her own experiences or sexualities, but through the dynamic and inter-subjective process of writing itself, whose constant negotiations both exemplify and exacerbate her multiple attachments to the dialogue itself, that 'big, spreading field of intimacy where love just grows wild' (214).

Elizabeth Stephens is an ARC Research Fellow at the Centre for the History of European Discourses, the University of Queensland. Her publications include Queer Writing: Homoeroticism in Jean Genet's Fiction (Palgrave Macmillan, 2009) and Anatomy as Spectacle: Public Exhibitions of the Body, from 1700 to the Present (Liverpool University Press, 2010).

\section{Works cited}

Derrida, Jacques. 'Countersignature.' Paragraph 27.2 (2004): 7-42.

—. Glas. Trans. John P. Leavey and Richard Rand. Lincoln: U of Nebraska P, 1990.

-. Of Grammatology. Trans. Gayatri Chakravorty Spivak. Baltimore: Johns Hopkins UP, 1976.

-. 'Signature, Event, Context.' Margins of Philosophy. Chicago: U of Chicago P, 1985. 308-330.

—. Signéponge/Signsponge. Trans. Richard Rand. New York: Columbia UP, 1984.

Dick, Kirby and Amy Ziering Kofman. Derrida. DVD. New York: Zeitgeist Video, 2003. 
Australian Humanities Review - Issue 48

Foucault, Michel. The History of Sexuality: An Introduction. Trans. Robert Hurley. London: Penguin, 1990.

Irigaray, Luce. This Sex Which Is Not One. Trans. Catherine Porter with Carolyn Burke. Ithaca, New York: Cornell UP, 1993.

Sedgwick, Eve Kosofsky. ADialogue on Love. Boston: Beacon Press, 2000.

—. Epistemology of the Closet. Berkeley: U of California P, 1990.

—. Tendencies. Durham: Duke U Press, 1993. 